\title{
Analýza procesu profesionalizace $v$ občanském sektoru očima jeho aktérů
}

\author{
Magdaléna Šfoviččová Jantulová
}

S růstem významu expertního vědění ve společnosti (Bell 1976, Inglehart 1989) se zvyšuje počet profesionálů jak $\mathrm{v}$ zaměstnaneckých oblastech a sociálních skupinách, ve kterých již dříve působili, tak v nových oblastech a skupinách. Profesionálové konstituují v těchto oblastech sociální řád, a tak se podílejí na určité regulaci jednání a vytváření kontrolních mechanismů. Nové formy regulace a kontroly, které se s profesionály objevují, restrukturují také mocenské vztahy mezi aktéry. S rostoucím požadavkem na expertnost v moderní společnosti roste i sociální status profesionálů, kteří reprezentují sociálně uznané expertní vědění (Beckman 1990). Nově se legitimizuje jejich mocenská pozice, což má vliv na nové uspořádání vztahů mezi nimi a laiky.

Tato stat' bude věnována profesionalizaci občanského sektoru v ČR a jejímu vlivu na změnu probíhající v kultuře a organizační struktuře neziskových organizací. Konkrétně se bude jednat o změnu rolí dobrovolníků a celkové uspořádání mocenských vztahů po př́ichodu nových aktérů - profesionálů - do těchto organizací. Dále bude, s využitím integrace organizační teorie a studia dobrovolnictví, potažmo profesionalizace v neziskovém sektoru, věnována pozornost možným změnám, ke kterým dochází v důsledku profesionalizace v oblasti cílů a strategií neziskových organizací: komplexitě, formalizaci a specializaci.

$\mathrm{K}$ popisu a pochopení procesu profesionalizace a některých z jeho konsekvencí bude využito př́padové studie jedné české ekologické neziskové organizace. ${ }^{1}$ Tato př́padová studie je jednou ze studií, které vznikly v rámci mezinárodního výzkumu neziskových organizací. ${ }^{2}$ Záměrem je doplnit teoretické diskuse o empirická zjištění, jež mohou přinést odpovědi na otázku, „co se děje v neziskovém sektoru“, a to formou rekonstrukce významů, kterými se aktéri dané neziskové organizace řídí a na základě nichž konstruují své jednání.

\section{Profesionalizace}

V odborné sociologické literatuře se termín ,profesionalizace“ nejčastěji objevuje v kontextu označování procesů, které vedou $\mathrm{k}$ formování profesí. Jedná se o proces, v rámci kterého určitá zaměstnání získávají charakter akademické profese. Vstup do takovéhoto profesního pole je podmíněn relevantním expertním věděním, které je možné získat jen v rámci specializovaných vzdělávacích institucí a je symbolizováno odpovídajícím titulem (Siegrist 1990).

Někteří autoři spojují proces profesionalizace s ustanovováním určitého rámce vědění a dělby práce. Profesionalizace, uvádí Seippell (2002: 262), v tomto smyslu „implikuje, že 
jedna skupina je schopna využívat exkluzivně své vědění a vzdělání $\mathrm{k}$ řešení specifických sociálních problémů, které společnost chce řešit“. Tato skupina - profesionálové - získává na základě tohoto svého vědění autonomii a monopol na řešení určitých problémů. Laik se tak stává závislým na profesionálovi (expertovi), který má monopol na řešení daného problému.

Třetí možný přístup, který se dle Siegrista (1990) objevuje v odborné literatuře, označuje profesionalizací proces, kdy se jedinci snaží získat vyšší sociální a ekonomický status, a to formou monopolizace zaměstnaneckých př́ležitostí a funkcí. $V$ rámci profesionalizace, uvádí Seippell (2002), dochází k distribuci rolí a k uspořádání vztahů moci a autority mezi profesionály (experty) a laiky vzhledem k sociálnímu statusu, který je odvozován od speciálního vědění. Laik se na základě nedostatku relevantního vědění stává závislým na profesionálovi při řešení specifických problémů, a profesionál tak získává autoritu, která je legitimizována jeho expertní věděním. Klasickým př́íkladem je profese lékaře.

Za čtvrté můžeme nahlížet proces profesionalizace z perspektivy sociologie organizace. $\mathrm{V}$ rámci procesu profesionalizace dochází $\mathrm{k}$ rozvoji specifického typu kolektivního vědomí, organizace, a také ke kolektivní reprezentaci zájmů a společných strategií. Škálu profesionálních praktik, norem a hodnot určují a dodržování výše uvedených u svých členů také kontrolují samotné profesní asociace, které také usilují o uznání těchto norem a praktik jinými sociálními skupinami.

Jak je patrné z tohoto krátkého přehledu, termín „profesionalizace“ je používán pro označení různých typů procesů, které vedou k rozvoji profesí. Jedná se především o procesy spojené se vzděláváním, dělbou práce, oblastí politické a sociální moci. Společné pro všechny tyto procesy však je, že zvyšují kulturní, sociální a ekonomický status aktérů a také jejich socio-politickou moc. Všechny tyto procesy jsou ovlivňovány profesními strategiemi, které slouží jako návod pro specifickou formu jednání a aktivit (Siegrist 1990).

Pro pochopení procesu profesionalizace a jeho konsekvencí v oblasti neziskového sektoru je třeba jmenovat ještě jeden relevantní koncept. Na základě socioekonomické povahy neziskového sektoru je možno profesionalizací označit také proces nahrazování dobrovolné práce prací placenou (Horch 1994: 223).

\section{Proces profesionalizace neziskových organizací}

Hartmann-Tews (in Sieppel 2002) na základě svého výzkumu uvádí tr̆i fáze, ze kterých proces profesionalizace sestává. První z nich se vztahuje k potenciálu pro profesionalizaci, druhá se pojí s formováním pravidel a norem a třetí je fází stabilizace.

Potenciál pro profesionalizaci vychází z rozvoje expertní kultury a rozšiřování hodnot a norem této expertní kultury ve společnosti. Převládá přesvědčení, že určitý problém může být řešen jen tím, kdo má specifické, formalizované vědění.

V neziskových organizacích, které reagují na vlivy prostředí, ve kterém působí, se institucionalizuje režim vědění související s určitými rolemi a postupně vznikají pracovní pozice, jejichž vykonávání je podmíněno určeným specifickým věděním. Požadováno je vědění, které je možné získat formou speciálního vzdělání, které musí být doplněno určitou praxí a zkušenostmi. O jaké vědění půjde a které role budou podmíněny expertním věděním, je určováno těmi, kteří dané vědění mají. 
Institucionalizované strategie jednání zpětně ovlivňují povahu a způsob jednání jedinců v neziskových organizacích. Dochází ke specializaci, formalizaci jednotlivých rolí a hierarchizaci struktury. Profesionální práce se monopolizuje (tj. fungování organizace se stává závislým na lidech se specifickým věděním) a diferencuje se ve vztahu k dobrovolnické práci.

Na druhé straně profesionalizace zvyšuje autonomii organizace a pozitivně ovlivňuje její efektivitu. Je to cesta, jak se neziskové organizace mohou stát partnery pro stát a trh v době, kdy je expertní vědění považováno významné.

\section{Profesionalizace a teorie moci}

O profesi hovoříme, pokud určitá skupina lidí využívá specifické formální vzdělání k realizaci specifického zaměstnání, které na základě sociálních norem nemůže být vykonáváno lidmi bez tohoto specifického vzdělání (Torgersen 1981 in Sieppel 2002). Znamená to tedy, že profesionalizace se pojí se skupinou jedincủ, kteří jsou schopni využít své vědění nebo vzdělání, které je v mnoha ohledech jedinečné, pro řešení specifických sociálních problémů (Sieppel 2002: 262).

Expertní teorie považují za zdroj profesního statusu expertní vědění. Profesionálové získávají na základě tohoto svého specifického vědění určitou autonomii, monopol na řešení určitých problémů, a tak i moc. Teorie moci naopak moc a společenské postavení profesionálů v moderní společnosti odvozuje od ekonomických a sociálních zisků profesionálů či je vysvětluje prostřednictvím konstruování a uplatňování sociálního rrádu a kontroly. Autorita profesionálů se odvozuje od přesvědčení druhých (klientů), že existují určité specifické dovednosti, které ovládají právě jen profesionálové. Specifická pozice expertů ve společnosti tedy vychází ze sociálních vztahů a ne prímo z povahy vědění a dovedností jedinců. Jiné mocenské teorie spojují moc profesionálů s organizací profesionálů. Tyto teorie poukazují na to, že profesní zájmové skupiny získávají kontrolu např́klad nad oblastí produkce nových profesionálů či nad podmínkami profesní práce. Profesní asociace vykonávají tuto kontrolu hlavně v oblasti vzdělávání a regulace profesní činnosti formou profesních licencí. Limitování profesní činnosti přispívá $\mathrm{k}$ vyššímu statusu a autonomii profesionálů ve společnosti, což jim přináší jak ekonomické, tak sociální zisky.

Důležitým tématem teorie moci v souvislosti se studiem procesu profesionalizace je tedy utváření vztahů moci a autority a dále jejich legitimizace. Jedním z nejvýznamnějších sociologů, kteří se věnovali otázkám moci a její legitimizace, byl Max Weber. Weber vymezuje moc jako šanci jednajícího prosadit v rámci určitého sociálního vztahu svoji vlastní vưli, a to i přes odpor druhých (Keller 2004: 273). Jeden z typů vztahů mocenské nerovnosti Weber označuje jako panství. Jedná se o vztahy mocenské nerovnosti, které jsou vnímány ze strany těch, kteří jsou moci podrobeni, jako oprávněné a nevnímají svou poslušnost jako vynucenou. Tyto nerovné vztahy fungují proto, že jsou považovány za oprávněné - legitimní.

Otázkou je, jak ti, kteří chtějí udržet své panství, ospravedlňují svou moc a činí nerovné sociální vztahy a jednání $\mathrm{v}$ rámci těchto vztahů přijatelnějšími. Weber představuje tři formy legitimizace, přičemž jedna z nich může být využita pro vysvětlení, jak jsou ospravedlňovány nerovné sociální vztahy mezi profesionály a neprofesionály.

Jedná se o způsob legitimizace, při němž je dle Webera platnost př́kazů zdůvodněna systémem záměrně vytvořených racionálních pravidel. Moc je tedy vnímána jako legitimní, když odpovídá systému přijatých racionálních pravidel. Aby pravidla měla obecně závaz- 
nou platnost, musí je vydat ten, kdo je dle těchto pravidel k tomuto kompetentní. Poslušnost není vyžadována vůči konkrétním osobám, ale je orientována normami majícími neosobní právní formu. ${ }^{3}$

\section{Aktéři neziskového sektoru - role a strategie jednání}

V souvislosti s profesionalizací neziskových organizací dochází také $\mathrm{k}$ proměně typů aktérů a jejich rolí a strategií jednání v organizaci. Jaké typické role a strategie jednání jsou připisovány hlavním aktérům občanského sektoru, dobrovolníkům, a novým aktérům - profesionálům?

Dobrovolníci jsou členové neziskových organizací, kteří vykonávají činnost v daných organizacích dobrovolně. Za dobrovolnou práci je označována práce, která není placená, je dobrovolně vykonávaná, slouží i jiným lidem než jen rodinným prŕíslušníkům. Jedná se tedy o servis pro druhé, který má jistý formální charakter (Ibsen 1992 in Sieppel 2002). Liší se tak od práce v domácnosti, která je také neplacená. Dobrovolná práce je považovány za jeden ze základních zdrojů dobrovolných, neziskových organizací. ${ }^{4}$ Jedná se především o čas a vědění, které dobrovolníci organizaci poskytují a které přináší prospěch dalším lidem.

Dobrovolníci, kteří nějakou činnost v neziskových organizacích vykonávají, vyjma toho, že tvoří významné zdroje pro tyto organizace, budují během těchto aktivit, které realizují s dalšími členy organizace, závazné a autentické vztahy jak s ostatními dobrovolníky, tak také s organizací (Lawler 2002 in Sieppel 2002). Tyto vztahy nejsou vnímány jako vztahy pracovní, založené na dělbě kompetencí a formálních pravidlech, ale spíše se jedná o vztahy přátelské, postavené na osobních neformálních vazbách, vzájemné důvěře a kooperaci mezi aktéry i mezi aktéry a organizací. Vztahy důvěry poskytují aktérům jistotu a slouží jako potenciál pro jejich další participaci na společných veřejných aktivitách i jako základ sociálního kapitálu ve společnosti (Putnam 1993).

Dobrovolníkům je připisována role autonomních kritických aktérů, kteří mají svá práva, ale i své závazky vůči společným cílům a ostatním aktérů. Jedinci mající možnost se př́mo podílet na rozhodovacích procesech, aktivitách organizace a spolupráci s jinými institucemi, tak získávají zkušenost z fungování institucí a větší důvěru v jejich fungování (Putnam 1993). V rámci společných aktivit se dobrovolníci také učí sociálním a občanským dovednostem jako např́klad jak vést setkání, mluvit na veřejnosti, psát dopisy, organizovat projekty, diskutovat veřejné otázky (Verba 1995: 304-333).

Dobrovolníci využívají občanská sdružení také k vyjádření a prosazování svých zájmů a požadavků vůči státu a přispívají tak k demokratizaci společnosti. ${ }^{5}$ Dobrovolníci však nejen prezentují veřejné zájmy, ale také konají veřejný dohled nad státní mocí a upozorňují na situace, kdy stát jedná v rozporu se zájmy veřejnosti (Tocqueville 1992: I/67, 72).

Jejich jednání není motivováno budováním vlastní profesní kariéry či dosahováním materiálního zisku, ale jak uvádí Marada (2003: 166), spíše osobním přesvědčením a snahou o politickou nezávislost na státní moci. Dobrovolníci jsou považováni za reprezentanty zodpovědného občanství.

Ideální typ profesionála popsal na základě sociologické literatury o zaměstnání Ernest Greenwood (Vollmer a Mills 1966: 10). Představuje pět základních rysů, které tvoří vnitřně koherentní obraz profesionála a na základě kterých se profesionálové odlišují od neprofesio- 
nálů. Pro profesionály je dle Greenwooda (tamtéž: 10) charakteristické využívaní systematické teorie a technických dovedností, užívání specifické autority, pravidel a sankcí, které jsou stanoveny širší komunitou profesionálů, etických standardů, které regulují vztahy profesionálů i neprofesionálů, a specifická profesní kultura.

Profesionálové se od neprofesionálů odlišují specifickým věděním a množstvím dovedností. Vědění profesionálů má teoretický základ. Jde o „systém abstraktních tvrzení, která v obecných termínech popisují třídy fenoménů, které jsou bodem zájmu profesionálư“ (tamtéž: 11).

Specifické vědění a dovednosti jsou základem pro profesní autoritu. Profesionál má dle Greenwooda (tamtéž) na rozdíl od neprofesionála na základě svého vědění moc rozhodovat o potřebách těch, kteří odpovídající vědění nemají. Profesionální autorita je však funkčně specifická. Je možné ji uplatnit jen v oblasti dané specializace, uvádí Greenwood. ${ }^{6}$

Jak bylo uvedeno výše, specifické vědění, které je profesionálům vlastní, je zdrojem jejich moci a prestiže. Moc profesionálů je reprodukována na základě pravidel, která si stanovují pro svou činnost a jejichž dodržování je kontrolováno samotnými profesionály v rámci jejich komunit. „Standardy pro profesionální činnost jsou ustanovovány na základě konsensu mezi samotnými profesionály a vychází z existující teorie“ (tamtéž: 14). Vztahy profesionálů jsou charakteristické emoční neutralitou. Servis je poskytován bez ohledu na konkrétní osobnost klienta.

V rámci svého jednání ve formálních a neformálních sítích profesionálové vytvářejí specifickou profesní kulturu - hodnoty, normy a symboly - která se liší od kultury jiných institucí. Mezi základní hodnoty profesních skupin dle Greenwooda (tamtéž: 16) patří poskytování servisu. Dále je za hodnotu považována racionalita.

Profesní kulturu si profesionálové osvojují během svého vzdělávání a dále pak v rámci interakce s ostatními profesionály v profesních asociacích během své kariéry. V rámci profesní kariéry se jedná o stejně důležitý proces jako osvojování si teoretických znalostí a technických dovedností (tamtéž: 18). Právě specifická kultura profesionálů je podstatou problémů v komunikaci a spolupráci mezi profesionály a neprofesionály.

\section{Případová studie - představení občanského sdružení}

Občanské sdružení, které bude objektem našeho výzkumného zájmu, patří k organizacím, jež se staly jedním z reprezentantů občanského sektoru - jak zdůrazňováním svého opozičního politického postavení vůči státu, tak principu uvědomělého občanství aktivně participujících občanů.

Toto sdružení vzniklo v roce 1990 a dnes působí vyjma Prahy a Brna v dalších šestnácti městech České republiky. V organizaci pracují jak dobrovolníci, tak v současnosti také asi 30 zaměstnanců, z nichž většina (20 osob) působí v brněnské centrále, kde je situováno jak vedení organizace, tak vedení jednotlivých projektů a servisní pracovníci. Brněnská pobočka za posledních několik let prošla nejvýznamnější změnou, a to od pobočky, kterou tvořili jen dobrovolníci, k centru celonárodní organizace, kde působí většina zaměstnanců organizace a kde probíhá koordinace většiny projektů, které organizace realizuje. Brněnskou pobočku vede ředitel, který byl dlouhou dobu také předsedou celé organizace. To přispělo k tomu, že se stala centrem organizace, v němž probíhá hlavní část plánování a rozhodování. 
Regionální pobočky organizace mají vlastní právní suverenitu. Většina z nich je tvořena dobrovolníky. Některé z nich však mají také své zaměstnance (jako např́iklad Olomouc). Regionální pobočky se podílí jak na celostátních kampaních organizace, tak realizují i vlastní projekty.

Všichni členové organizace sdílejí informace prostřednictvím měsíčně vydávaného časopisu a v rámci jednotlivých projektů. Jednou ročně se scházejí na společném zasedání, kde je diskutována strategie organizace i jednotlivých projektů.

\section{Proces profesionalizace očima aktérů}

Profesionalizace je pojem, který se objevuje v posledních letech čím dál častěji jak v oficiálních, tak neoficiálních materiálech neziskových organizací, v rámci jejich vnitřních diskusí i diskusí v médiích. Slyšíme, že neziskové organizace se profesionalizují, jejich cílem je realizace profesionální činnosti atd. S jakými procesy profesionalizaci spojují samotní aktéři těchto organizací?

Členové naší neziskové organizace hovoří o profesionalizaci jako o jedné z významných změn, které se v organizaci udály v posledních letech. Pojem profesionalizace používají v několika významech. Profesionalizací označují proces najímání odborníků, kteří mají určité specifické vědění, jež využívají pro realizaci odborné činnosti a řešení problémů organizace. ${ }^{7}$ Nejčastěji se jedná o pracovní pozice spojené se získáváním finančních prostředků, komunikací s médii a veřejností, strategickým plánováním činnosti a její organizace, účetnictvím.

Profesionalizací členové organizace dále označují procesy, které vedou ke zvyšování kvality a efektivity činnosti organizace. Jedná se například o využívání činnosti odborníků či zaměstnávání pracovníků na celý či částečný úvazek, formalizaci organizační struktury či využívání strategického plánování.

Z organizačního hlediska znamená profesionalizace dělbu práce. V organizaci už „,nedělají všichni vše“ jako dříve, ale práce je rozdělována na základě přesných pravidel, a to hlavně na základě specializovaného vědění. Dělba práce se tak povětšinou pojí se specializací práce. Specializovaly se takové činnosti jako získávání financí, vydávání publikací, komunikace s médii, správa webových stránek atd., ale také aktivity v rámci jednotlivých projektů.

V neposlední řadě hovoří členové organizace o profesionalizaci v situaci, kdy aktéři za svou činnost v organizaci začínají pobírat mzdu. Nejsou již dobrovolníky ve smyslu vykonávání dobrovolné, neplacené práce, ale stávají se zaměstnanci organizace na částečný či celý pracovní úvazek.

\section{Kdo jsou profesionálové?}

Jak bylo řečeno, jako profesionálové jsou členy organizace označováni zaměstnanci organizace. První zaměstnanci organizace byli přijímáni převážně z řad dobrovolníků, kteří v organizaci pracovali již delší dobu a měli odpovídající zkušenosti na základě své dlouholeté činnosti v organizaci. Jako zaměstnanci organizace - profesionálové - vykonávali stejný typ práce jako dobrovolníci a ani jejich strategie jednání se zásadně nelišily. Tito jedinci využívali v rámci své práce sociální vazby s ostatními členy organizace, které získali v rámci předchozího působení v organizaci. 
Další fáze profesionalizace se liší od první fáze tím, že jsou během ní formou konkurzního řízení na jednotlivé pracovní pozice najímáni lidé, kteří dříve v organizaci nepracovali. Tito „novi““ profesionálové jsou vybíráni na základě jasných kritérií. Jedno ze základních kritérií, které začalo být uplatňováno, určovalo specifické znalosti a zkušenosti dle činnosti pro každou pozici. Tito noví zaměstnanci přinášeli do organizace jednak nové vědění, dále také vlastní zkušenosti z jiných neziskových i ziskových organizací a v souvislosti s tím i nové strategie jednání. Jejich zájem o činnost v dané organizaci byl primárně motivován získáním zaměstnání, které jim poskytne určité finanční zabezpečení a profesní kariéru. Tím, že tito lidé na rozdíl od prvních profesionálů v dané organizaci dříve nepracovali, neměli žádné osobní zkušenosti s činností organizace a také vytvořené sociální vazby s ostatními členy organizace. Byli vnímáni jako lidé ,zvenčí“.

\section{Role a typy aktivit profesionálů}

Profesionálové nejčastěji koordinují a realizují projekty organizace a zajišt'ují servis pro jednotlivé projekty v oblasti zastupování organizace na veřejnosti, účetnictví, př́pravě propagačních materiálů po stránce jazykové i grafické atd. Jedná se o činnosti, které jsou spojeny s procesy rozhodování o typech akcí a formách realizace, formulování pravidel, rozdělování úkolů atd. Ve srovnání s dobrovolníky zastávají v organizaci mocensky významnější pozici. Dobrovolníci spíše realizují činnost, která je jim určována profesionály. Jedná se převážně o servisní, jednorázové úkoly pro jednotlivé projekty či organizaci. Př́íkladem dobrovolnické práce je příprava nabídky práce pro dobrovolníky. Dobrovolník každý týden zpracuje a rozešle seznam činností, které jednotliví koordinátoři projektů potřebují zajistit pro svůj projekt.

Jak profesionálové, tak dobrovolníci uvádí, že se jejich role v organizaci liší. Profesionálové interpretují svou roli v organizaci vzhledem k roli dobrovolníka následovně: Profesionál věnuje činnosti v organizaci daleko více času než dobrovolník. Na základě svého vědění a vzdělání je kompetentní realizovat právě jen určité činnosti odpovídající tomuto jeho vědění a vzdělání. Dobrovolníci dle profesionálů mají omezené časové možnosti pro realizaci aktivit. Nemohou se proto spolehnout na pravidelnou a rychlou realizaci potřebných úkolů. Chybí jim často také specifické vědění, které by jim umožňovalo podílet se na spoluvytváření idejí a na rozhodování, a proto v organizaci spíše zastávají pasivní servisní roli.

Také dobrovolníci spatřují základní rozdíly mezi sebou a profesionály v časových možnostech, které mohou věnovat činnosti. Profesionálové jsou aktivní a iniciativní jedinci v organizaci, protože realizují aktivity během pracovní doby. Dále dobrovolníci upozorňují na rozdílné znalosti a také zkušenosti profesionálů, přičemž se jedná převážně o odborné znalosti a zkušenosti, nikoli zkušenosti získané během činnosti v organizaci.

Aktivity si dobrovolníci volí na základě svých časových možností, které považují ve srovnání s profesionály za značně omezené. Proto nejsou některé činnosti podle vlastního názoru schopni realizovat. Dále jim nedostatek podobných znalostí neumožňuje podílet se na činnosti a rozhodování společně s profesionály. Necítí se být dostatečně kompetentní, a proto dávají přednost spíše realizaci činnosti, která je jim přidělena. Slyšíme: „Nevím, jak bych mohl přispět. Necítím se být kompetentní." V neposlední řadě uvádí, že některé aktivity by měli realizovat jen profesionálové, protože ,jsou za ně placeni“‘. Profesionálové na rozdíl od 
dobrovolníků mají přesně určenou roli na základě své pracovní náplně, a tak je možno očekávané aktivity relativně přesně definovat. Tyto aktivity pak dobrovolníci odmítají realizovat.

Je patrné, že dobrovolníci svou roli konstruují na základě srovnání s profesionály a své jednání orientují na základě hodnot a norem, které v organizaci prezentují profesionálové. Př́kladem toho, jak důležitou roli hraje pocit kompetentnosti, který vychází z norem, jež jsou v organizaci pro činnost stanoveny a které ovlivňují jednání jedinců, je následující případ. Pokud se mezi dobrovolníky objeví člověk s určitým specifickým věděním, jako např́klad právník, je okamžitě zapojen do pracovního týmu a aktivně se podílí na realizaci konkrétních akcí, a to nejen formou plnění zadaných úkolů. Účastní se také rozhodovacích procesů a plánování, a to i přesto, že je dobrovolník a nemůže věnovat činnosti v organizaci tolik času jako profesionál. Dobrovolník s expertním věděním se dostává do mocensky významné pozice: zadává úkoly, podílí se na rozhodování a tvorbě strategií.

V neposlední řadě se ukazuje, že profesionálové ovlivňují a kontrolují stále větší oblast aktivit. Realizují činnosti, které dříve dělali dobrovolníci anebo které v organizaci nebyly realizovány. Určité činnosti jsou prováděny výhradně profesionály. Tito se navíc podílejí velkou měrou na servisu pro ostatní členy organizace, čímž dochází k implementaci jejich hodnot a pravidel v rámci celé organizace, jako např́íklad formou školení pro regionální organizace, což má několik pozorovatelných důsledků.

Za prvé se mění charakter aktivit organizace. Přibývá těch, jejichž realizace je závislá na činnosti profesionálů a potažmo také na finančních prostředcích. Dobrovolnická práce již není prvek podstatný pro realizaci aktivit organizace, což má za následek zvyšování množství finančních prostředků nutných pro jejich realizaci. Nejedná se však jen o potřebu většího množství financí, ale také o jinou strukturu výdajů a pravidelnost př́ijmů. Je potřeba více financí na odměny pro ty, kteří činnost realizují, než na prrímou realizaci projektu. Navíc tyto finance potřebuje organizace pravidelně. Tím vzrůstá závislost organizace na finančních prostředcích a potažmo na donorech.

Dále je patrná nižší participace dobrovolníků na celkové činnosti organizace. Otázkou je, proč se dobrovolníci nezapojují do určité činnosti (např́iklad proces plánování, rozhodování atd.), i když formální organizační podmínky dané jednání aktérů umožňují. Profesionálové deklarují možnost dobrovolníků například účastnit se schůzek a aktivit projektů v neomezené míře, předkládat návrhy k diskusi, získat veškeré informace atd. Na druhé straně však můžeme pozorovat, že v organizaci je kladen důraz na specializované vědění a dovednosti. Realizace většiny aktivit je deklarována jako časově náročná. Míra odborné a časové náročnosti většiny aktivit, jež byla v organizaci stanovena jako pravidlo, neumožňuje dobrovolníkům, aby participovali aktivně na jiných než jednorázových aktivitách, které mají spíše servisní charakter. Pravidla a z nich plynoucí očekávání tak negativně ovlivňují potenciál aktivní participace dobrovolníků v organizaci.

V neposlední řadě je jednání aktérů stále více podřizováno vědomé volbě. Dochází k určitému zreflexivňování subjektivní zkušenosti jedinců, na kterých byla činnost neziskové organizace dlouhou dobu založena, právě s využitím vědění expertů. V rámci této sociální reflexe dochází k určitému znejistění světa, ke zpochybňování přirozených opěrných bodů či přirozené nutnosti. ${ }^{8}$ Projevem tohoto znejistění jsou konflikty mezi profesionály (jejich věděním) a dobrovolníky (jejich zkušenostmi). Např́klad v nové strategii získávání finanč- 
ních prostředků, kterou připravili profesionálové, byly uvedeny ostatní neziskové organizace jako potenciální konkurenti. Členové organizace s tímto předpokladem nesouhlasili, protože je vždy považovali spíše za partnery než konkurenty. Realizovali společné akce, diskutovali možné strategie, mnohdy byli také provázáni osobními vazbami.

\section{Strategie jednání profesionálů}

Dle dobrovolníků ovlivňuje strategie jednání a aktivit profesionálů to, zda profesionálové „vyšli z daného prostředí“ organizace, zda dř́ve, než se stali zaměstnanci, pracovali v organizaci jako dobrovolníci, či zda přišli z jiné organizace, přičemž nezáleží na tom, zda neziskové, státní či ziskové. Noví profesionálové mají minimální osobní vazby s ostatními členy organizace. Dle zkušeností členů organizace nemá „člověk zvenčí“ tak silný pocit zodpovědnosti za organizaci a realizaci cílů. Dobrovolníci tuto svou zkušenost prezentují na př́iběhu, kdy byl přijat profesionál, jenž v organizaci dř́ve nepracoval jako dobrovolník, byl však z odborného hlediska vhodným kandidátem na danou pozici. Tento profesionál však záhy odešel, protože dostal lepší pracovní nabídku. Organizace se následně ocitla v potížích, protože nemohla realizovat plánovaný projekt, který měl zajištovat tento člověk. Dobrovolníky je jeho jednání vnímáno jako nezodpovědné a poškozující organizaci a potažmo i její členy, kteří usilují o dosažení společných cílů. Je zde tak patrné jiné vnímání důležitosti situace a kladení důrazu na jiné hodnoty u profesionálů a dobrovolníků, což se stává zdrojem konfliktů a vzájemné nedůvěry.

Odlišné strategie jednání profesionálů jsou podmíněny také tím, že se $\mathrm{v}$ jejich př́ípadě nejedná o dobrovolnou aktivitu, ale že tito v rámci činnosti v organizaci realizují své zaměstnání. Na tomto zaměstnání jsou závislí, protože je zdrojem základního finančního zabezpečení, a zároveň se jedná o činnost, v rámci které realizují a budují svou pracovní kariéru a společenský status. Jednání je proto spíše hodnotově neutrální, ovlivněno racionálními univerzálními pravidly, na rozdíl od dobrovolníků, jejichž jednání je spojeno s osobními zájmy o dosažení cílů a vyřešení problémů.

Profesionálové si své strategie osvojili v rámci studia, své praxe a interakce s ostatními profesionály. Tyto strategie považují za jediné správné. Dávají přednost „objektivním“, univerzálním kritériím, která jsou nezávislá na jednotlivých osobních vztazích. Spíše než jednání založenému na určité tradici dávají přednost racionálnímu jednání. Patrné je to na situaci, kdy se v organizaci rozhodovalo, zda na veřejnou propagační kampaň najmout profesionální agenturu, která na její realizaci zaměstná lidi, nebo zda využít dobrovolníků pracujících v organizaci. Profesionálové prosazovali využít služeb profesionální agentury. Její výhodu spatřovali v záruce, že kampaň proběhne ,profesionálně“. To znamená, že předem budou stanovena jasná pravidla a s lidmi, kteří se budou na kampani podílet, bude uzavřena smlouva, v níž budou jasně stanoveny závazky těchto jedinců vůči organizaci. Výhodou využití členů-dobrovolníků by dle profesionálů bylo zlevnění kampaně a reprezentace a propagace organizace lidmi, kteří jsou ztotožněni s jejími cíli a strategiemi organizace a mají osobní zkušenost z realizací aktivit organizace. Na druhé straně není možné od těchto aktérů získat jiný typ závazku, než jejich osobní slib. Vztah s dobrovolníky je možno založit na di̊věře $v$ jejich zodpovědnost a zájem, nikoli na jasně stanovených pravidlech garantovaných písemnou smlouvou. 


\section{Formy legitimizace profesionálů $v$ organizaci}

Jak legitimizují sociální vztahy a jednání profesionálů a dobrovolníků samotní aktéŕi? Autorita profesionálů je odvozována od institucionálního systému pravidel a rolí, jež jsou uznávány členy organizace. Pravidla obsahují především požadavky na specifické vědění a zkušenosti vzhledem $\mathrm{k}$ cílům a úkolům, které profesionálové $\mathrm{v}$ organizaci vykonávají. Tato pravidla jsou jasně deklarována zejména v rámci přijímacího rízení, během něhož organizace volí vhodného kandidáta.

Autorita profesionálů je tedy sociálně určena, a proto záleží na tom, zda jsou tato institucionální pravidla přijata jako určité návody pro jednání všemi členy organizace. V naší organizaci je patrné, že tato pravidla byla akceptována jen částí členů, a proto ne plně legitimizují jednání profesionálů.

Na jedné straně dobrovolníci prrijali a orientují své jednání na základě těchto pravidel. Jak již bylo řečeno, určité činnosti přenechávají dobrovolníci výhradně profesionálům, kteří mají odpovídající specifické vědění, zkušenost, ale také časové možnosti, které jim umožňují realizovat činnosti dle ,profesionálních“ kritérí.

Na druhé straně je možno pozorovat, jak mezi profesionály a dobrovolníky vznikají konflikty. Jedná se o situace, kdy dobrovolníci odmítají jednat podle pravidel, jež jsou prosazována profesionály. Při tvorbě strategie propagace organizace za účelem oslovení potenciálních donorů připravil tým profesionálů návrh strategie, který obsahoval návrhy činností, jež odpovídaly odborným standardům $\mathrm{v}$ dané oblasti - nová kampaň zaměřená jen na propagaci činnosti organizace, využití billboardů k propagaci činnosti organizace atd. S těmito navrhovanými strategiemi jednání však nesouhlasili dobrovolníci, protože přesto, že navrhované strategie jednání odpovídaly odborným standardům, byly v rozporu s jejich základními hodnotami. V organizaci vznikl spor, zda se má dále postupovat na základě strategie vypracované profesionály, kteří mají odpovídající specializované vědění pro danou činnost, či zda mají být zohledněny názory dobrovolníkủ, které nevychází z odborných znalostí. $\mathrm{V}$ tomto př́padě formální zdůvodnění jednání expertů a jejich autority na základě institucionalizovaných pravidel nebylo dobrovolníky přijato - profesionální autorita $\mathrm{v}$ tomto př́padě nezískala potřebnou váhu, aby byla navrhovaná strategie jednání přijata.

Postupně však dochází ke stále významnějšímu prosazování institucionálního systému pravidel, který legitimizuje autoritu expertů. Děje se tak jednak přijímáním stále většího množství profesionálů do organizace, kteří tato pravidla v rámci své činnosti uplatňují, a tím také reprodukují. Profesionálové rovněž zastávají v organizaci pozice, které jsou mocensky významné. Řídí a koordinují činnost v dané pracovní oblasti a poskytují odborný servis ostatním členům (jak dobrovolníkům, tak profesionálům). Jedná se např́klad o psaní projektů, oslovování veřejnosti, organizace práce atd. V rámci poskytování tohoto servisu dochází k rozšiřování určitých standardů, hodnot a norem profesionálů, které následně ovlivňuje jednání ostatních členů. V neposlední řadě jsou institucionální pravidla a způsoby jednání profesionálů v organizaci rozšiřovány např́íklad formou školení, které profesionálové připravují pro místní skupiny organizace a v rámci nichž poskytují návody, jak jednat.

Je zde možno pozorovat, že členové organizace vnímají také vnější institucionální tlak, který ovlivňuje uznání a legitimitu institucionálních pravidel. Jedná se jednak o rostoucí tlak na profesionalizaci a specializaci v současnosti zejména ze strany donorů a konkurence. Aby organizace mohla realizovat aktivity naplňující její cíle a obstát v konkurenci dnes již nejen 
vůči státu, ale i tržním organizacím, vnímají členové nutnost přizpůsobit se požadavkům a standardům donorů a partnerů a také si zachovat svou legitimitu. Jak uvádí jeden z dlouholetých členů organizace: „Doba to vyžaduje. Už to nejde dělat jako doposud.“9

A jak profesionálové interpretují svou autoritu? Profesionálové jednají na základě jasných racionálních pravidel, jichž také využívají pro legitimizaci svého jednání a pozic v rámci sociálních vztahů v organizaci. Vycházejí z předpokladu, že racionální a odborné argumenty expertů jsou ospravedlnitelné a nezahrnují možnost diskuse o těchto argumentech. Je to patrné z jejich interpretace výše popsaného konfliktu o podobu kampaně, který vznikl mezi nimi a dobrovolníky. Př́ícinu konfliktu vidí profesionálové ve špatné informovanosti a nedostatečném vysvětlení strategií členům organizace. Svůj úkol vidí v tom, přesvědčit členy o správnosti a efektivnosti navrhované strategie, a to formou jasných informací a argumentů s odvoláním na své odborné vědomosti a zkušenosti v daném oboru. „Kdo se jenom trochu zajímá o PR ví, že je to nejefektivnější cesta, jak propagaci činnosti organizace zajistit.“

Autorita profesionálů, která má formálně-racionální charakter, se v organizaci střetává s typem autority, který byl pro organizaci typický dlouhá léta. Jedná se o neformální charismatický typ spojený s autoritou konkrétních osob. V současnosti tento typ autority v organizaci přetrvává. Využívá ho určitá malá skupina jedinců, kteří v organizaci působí již dlouhou dobu. Tato jejich autorita není specifická, není omezena konkrétními pravidly. Členové organizace těmto lidem důvěrují a identifikují se s nimi bez ohledu na to, zda se jedná o způsob financování či typy aktivit v rámci kampaně.

$\mathrm{V}$ organizaci nedochází k žádnému konkurenčnímu boji mezi těmito autoritami. Charismatická autorita je spíše postupně narušována autoritou profesionálů a je využívána jen v př́padech, kdy důvěra profesionální autority není přijímána.

\section{Organizační změny}

Jak již bylo uvedeno, členové organizace profesionalizací označují mimo jiné proces související se změnou organizačního uspořádání a pravidel. ${ }^{10}$

V rámci profesionalizace organizace byly vytvářeny specializované pozice, jež byly definovány jasně určeným typem činnosti a také požadovaným vzděláním a zkušenostmi. Každá takováto pozice byla obsazena jedincem s odpovídající kvalifikací, který se stal také zodpovědným za realizaci činnosti, jež byla spojena s danou pozicí. Dochází tak k určité specializaci a zároveň $\mathrm{k}$ dělbě práce. Činnosti, které dříve dělal jeden člověk, se rozdělují mezi více osob dle jejich specializace. Naprríklad byla vytvořena pozice editora, který prripravuje na základě podkladů jednotlivých projektů publikace, které organizace vydává. Dříve si každý projekt připravoval své publikace sám. Nyní dodají informace či materiály editorovi, který texty píše, dělá korektury textů atd.

Proces profesionalizace souvisí také se systematickým budováním organizační struktury a psaných pravidel ř́zení, komunikace, práce s dobrovolníky, získávání financí, propagace organizace atd. Cílem této reformy, jak uvádí člověk, který byl do organizace přijat, aby tuto reformu připravil - byla určitá „systematizace a dělba práce“. Dle profesionálů, kteř́ tuto reformu připravovali, organizace doposud fungovala amatérským způsobem - tzn. nesystematicky, s minimální diferencovaností funkcí i činností. 
Je tedy patrná snaha formalizovat a racionalizovat jednání a vztahy v organizaci pomocí pravidel, která by měla univerzální charakter. Tato pravidla již nejsou odvozována od osobních zkušeností aktérů a tradic a jsou platná bez ohledu na osobní vztahy členů organizace, jak tomu bylo dřive, což podle profesionálů bránilo racionálnímu fungování organizace. Mění se např́iklad situace, v níž nebylo v systému vztahů založených na osobních vazbách možné používat principu př́ikazů. Nová univerzální pravidla ustanovují a legitimizují vztahy podřízenosti a nadřízenosti, a umožní tak používat principu příkazů.

Tyto organizační změny samozřejmě podmiňují způsoby jednání a regulaci vzájemných vztahů členů. V rámci dělby práce, která je spojená se specializací a také se zvětšováním rozsahu realizovaných aktivit, ubývá prostor pro spolupráci mezi členy organizace. Stoupá tak míra anonymity v organizaci. Spolupráce a osobní vazby jsou rozvíjeny jen v rozsahu daného projektu či aktivity. Organizace tak již není sítí jedinců, kteří se vzájemně znají.

Hierarchická organizační struktura také determinuje př́stup k informacím a k participaci na rozhodování. Př́ístup je omezen na aktivní participanty. „Pokud se člověk zeptá a zajímá se o informace, vše se dozví.“ Dobrovolníci dostávají nabídku činností, do kterých se mohou zapojit. Jedná se o velice konkrétní a také většinou časově omezenou činnost.

Je však nutné poznamenat, že na druhé straně potenciál dobrovolnické participace stále ovlivňují osobní kontakty aktérů s ostatními členy organizace. Tyto osobní vztahy jsou jak zdrojem informací, tak zdrojem důvěry. Participace na činnostech organizace a podílení se na neformálním strategickém rozhodování závisí na tom, zda je jedinec součástí osobních sítí členů organizace a má jak potřebné informace, tak důvěru v ostatní členy.

V souvislosti se specializací práce získávají profesionálové určitý stupeň autonomie. Každý vykonává svou práci nezávisle na ostatních. Rozhoduje a je zodpovědný jen za svou práci. Jak uvádějí členové organizace, jak z důvodů časových, tak i odborných již ,nezasahují do činnosti jiných“. Např́klad dobrovolník přicházející do organizace zná jen úzkou skupinu lidí, kteří mu práci zadávají a se kterými na dané činnosti spolupracuje. Nevytvárí se tak již široké sociální sítě, které mohou být zdrojem kooperace a sociální důvěry. ${ }^{11}$

Formalizace pracovních postupů má také vliv na pluralitu činností. Profesionálové na základě svého vědění a zkušeností předkládají určité strategie jednání, které - jak sami uvádějí - mají ,jen omezené množství variant jednání“, pokud mají být efektivní. Omezuje se tak repertoár aktivit a způsobů jednání, které jsou v organizaci považovány za možné a přijatelné.

Vrat'me se ještě jednou $\mathrm{k}$ př́padu, kdy organizace přijala profesionála na koordinaci nového projektu, ale ten záhy odešel za lepší pracovní nabídkou, důsledkem čehož organizace nemohla projekt realizovat. Je patrné, že vzhledem k dělbě práce, která se děje na principu specializovaného vědění, dochází k tomu, že jedinci ve svých specializovaných rolích nejsou zastupitelní, čímž se snižuje do určité míry flexibilita organizace. Omezují se tak možnosti realizace určitých činností na ty, pro které má organizace odpovídající odborníky a následně i finanční prostředky pro zajištění těchto odborníků.

V souvislosti s profesionalizací dochází na druhé straně také k rozšiřování skupiny lidí, kteří se podílejí na mocensky významném rozhodovacím procesu. V organizaci byla malá silná skupina lidí, kteří měli ,„prirozenou“ autoritu, jež vycházela z jejich osobních zkušeností a dlouholetého působení v organizaci. ${ }^{12}$ Jednalo se převážně o lidi, kteří se podíleli na zakládání organizace a byli vnímáni jako ti, kteří mají nejen zkušenosti, ale i určitou představu o dalším směřování organizace. 
Profesionálové se na základě svého odborného vědění zapojují do rozhodování a činnosti této úzké skupiny. Dochází ke změně organizační struktury. Kompetence ředitele organizace se rozdělily mezi několik lidí dle určité specializace. Diskuse a rozhodování neprobíhá na jedné poradě, ale jsou organizovány specializované porady k jednotlivým tématům. Na klíčových rozhodováních a tvorbě strategie se tak podílí širší skupina lidí než dříve.

\section{Závěr}

Cílem této práce bylo představit významy některých aspektů procesu profesionalizace v neziskovém sektoru, jež prezentují samotní členové jedné neziskové organizaci - a to jak dobrovolníci, tak profesionálové.

Je patrné, že proces profesionalizace $\mathrm{v}$ neziskovém sektoru nesouvisí s formováním nové profese, ale je spíše reakcí na institucionální tlak na expertnost a uplatňování určitého vědění, které je určeno za základ pro řešení daných sociálních problémů. Dochází k monopolizaci určitých pracovních činností a př́iležitostí. Činnost, kterou dříve vykonávali dobrovolníci, je realizována převážně profesionály, kteří mají odpovídající vzdělání a zkušenosti. Dobrovolníci již nemohou jejich pozice zastávat ani kontrolovat jejich činnost. Roste tak nerovnost mezi aktéry v organizaci.

S rostoucími požadavky na specializaci přibývá počet členů, jež můžeme nazvat „novi““ profesionálové. Jedná se o jedince, kteří jsou přijímáni v rámci výběrového řízení na základě odpovídajících znalostí a zkušeností na předem určenou pozici. $V$ organizaci však dříve nepracovali a neznají tak poslání a činnost organizace ani nemají sociální vazby s jejími členy. Práce v organizaci je jejich profesí, ne dobrovolnou aktivitou, v rámci které by prosazovali zájmy své i ostatních bez nároků na finanční ohodnocení. S př́chodem těchto „nových“ profesionálů se v organizaci objevují nové strategie jednání, které si tito jedinci osvojili v průběhu svého vzdělání a pracovních zkušeností jak v neziskovém, tak také státním či ziskovém sektoru.

Tyto strategie jednání, které se postupně institucionalizují jako všeobecně platné strategie jednání v organizaci, ovlivňují postupně jednání všech členů organizace. Cíle organizace zůstávají stejné, liší se však způsob jejich realizace. Vytváří se standardy, které podmiňují určité jednání expertním věděním, což ovlivňuje pocit kompetentnosti dobrovolníků pro výkon dané aktivity. Vznikají také časové standardy, které ovlivňují očekávání, kolik času je dané aktivitě třeba věnovat, aby byla realizována efektivně. Dobrovolníci na základě těchto standardů hodnotí své časové možnosti jako nedostatečné pro realizaci určitých aktivit. V neposlední řadě je upřednostňován étos profesní před étosem občanským. Spíše než aktivity motivované osobními morálně politickými zájmy je pro svou efektivnost preferována profesní racionální motivace spojená s univerzálními pravidly a standardy jednání, které se také váží s vymahatelnými závazky.

Rostoucí požadavek na expertnost činnosti ovlivňuje také formy regulace a kontroly v organizaci a dochází k novému uspořádání mocenských vztahů mezi profesionály a dobrovolníky. Vztahy mezi aktéry jsou uspořádány hierarchicky. Vzhledem k novému rozložení moci vznikají v organizaci konflikty mezi skupinami, jež považují autoritu profesionálů za legitimní, a těmi, kteří ji neuznávají. Postupně však dochází k růstu významu autority profesionálů, a potažmo i $\mathrm{k}$ institucionalizaci struktury autority založené na institucionálně určených pravidlech. 
Můžeme také pozorovat, jak formálně racionální autorita profesionálů, která je odvozena od pravidel profesionálů a těmito pravidly legitimizována, postupně nahrazuje charismatickou autoritu malé skupiny jedinců a jak profesionálové získávají kulturní vliv a kontrolu.

S růstem moci profesionálů klesá význam dobrovolníků a jejich práce, což má vliv jak na finanční náklady organizace, které se zvětšují, tak na sociální roli neziskové organizace. V profesionalizované neziskové organizaci ubývá prostor pro tvorbu sociálního kapitálu a formování občanských dovedností. Dobrovolníci již méně a nepravidelně kooperují s ostatními členy organizace. Nejsou tak již vytvářeny rozsáhlé horizontální sítě vztahů a závazků, v rámci nichž dochází k formování sociální důvěry. Dobrovolníci se dostávají do role pasivních aktérů, kteří vykonávají činnosti, jež jsou jim určeny profesionály. Uplatňují své dosavadní vzdělání a dovednosti, spíše než by se učili novým občanským dovednostem.

V neposlední řadě dochází také k organizačním změnám, a to ke specializaci činnosti a v souvislosti s tím i dělbě práce a formalizaci pravidel jednání. Tyto organizační změny do určité míry omezují flexibilitu jednání, protože jedinci nejsou již zastupitelní a organizace je závislá jen na těch, kteří mají odpovídající vzdělání a zkušenosti. Na straně druhé se do procesů rozhodování zapojuje širší skupina lidí, protože jejich zapojení již není omezeno požadavkem dlouholetých zkušeností a osobními kontakty se členy organizace. Pro zapojení do rozhodování je důležitým kritériem odpovídající expertní vědění. V organizaci jsou tak narušeny oligarchické tendence lidí, kteř́ svou autoritu odvozovali od osobního charismatu. Jednání a aktivity jsou stále více podřizovány vědomé volbě. Dochází k růstu významu sociální reflexivity, sociální praktiky jsou neustále ověřovány a přetvářeny na základě informací, a nevychází se již jen z tradice.

\section{Poznámky}

1 Jedná se o jednu z významných ekologických neziskových organizací, která vznikla po roce 1989 na základě iniciativy skupiny občanů a postupně se stala organizací s celonárodním působením. Dnes má pobočky v 16 regionech a realizuje 6 hlavních projektů. Jejich činnost zahrnuje organizaci osvětových i vzdělávacích kampaní, přípravu a prosazování legislativních návrhů, účast na připomínkových řízeních, jednání s úřady a politiky v oblasti životního prostředí.

2 Projekt „Organizační inovace a interaktivní média v neziskových organizacích ve východní Evropě“, jehož realizátory byli D. Stark a L. Bruszt. Další informace o výzkumu na http://www.sociology.columbia.edu/people/faculty/stark/papers/innovation_media_ngos.pdf

3 Weber uvádí, že moc může být ospravedlňována také na základě osobní autority určitého jedince. Legitimní je to, „co je vžité, co vždy bylo tak a co ukládá poslouchat osobu hodnostáře“ (Weber 1997: 63).

Osobní autorita může být odvozena také od charismatu určitého jedince. Nositel charismatu je ostatními poslouchán a následován na základě své osobní kvalifikace a osvědčení, což ho předurčuje k určitému poslání.

$4 \quad$ Za základní charakteristiky dobrovolnických organizací se považují: dobrovolné členství, nezávislost organizace na státu a trhu, vnitřní demokratická rozhodovací struktura, dobrovolná práce, závazky organizace ke svým členům a dosažení specifických cílů (Horch 1994).

5 Warren (2001) mluví o třech způsobech, jimiž mohou neziskové organizace přispívat k demokratizaci společnosti: 1. tvorba sociálního kapitálu, 2. posilování veřejné sféry a 3. Umožňování reprezentace zájmů občanů. 
Později bude ukázáno, že moc, kterou profesionál má ve svém oboru, je zdrojem vysokého statusu, který již není funkčně specifický a zajišt'uje profesionálům moc nejen v jejich profesní oblasti.

Toto vymezení procesu profesionalizace se shoduje s vymezením Seippella (2002), jež bylo prezentováno v kapitole „Profesionalizace“ v úvodu stati.

$8 \quad$ Viz Giddens 1990.

Tento typ organizační změny vlivem normativního tlaku, který vyvíjí prostředí a v rámci kterého organizace jednají, popisují DiMaggio a Powell (1983) v teorii institucionálních modelů.

10 Viz kapitola „Proces profesionálů očima aktérů“.

$11 \quad$ Viz Putnam 1993.

12 Dle Weberovy typologie se jedná o charismatický typ panství (Weber 1997).

\section{Literatura}

Beckman, S. 1990. „Professionalization: Bordeline Authority and Autonomy in Work.“ In R. T. Burrage (ed.) Professions in Theory and History. Rethinking the Study of theProfessions. New York: Sage Publications.

Bell, D. 1976. The Coming of Post-Industrial Society: A Venture in Social Forecasting. New York: Basic Book.

DiMaggion, P. J., Powell, W. W. 1983. „The Iron Cage Revisited: Institutional Isomorphism and Collective Rational in Organizational Fields." American Sociological Review, 48, No. 2: $147-160$.

Giddens, A. 1990. Di̊sledky modernity. Praha: Slon.

Horch, H. 1994. „On the Socio-economics of Voluntary Organizations“. Voluntas 5: 219-230.

Inghlehart, R.1989. Culture Shift in Advanced Industrial Society. Princeton, NJ: Princeton University Press.

Keller, J. 2004. Dějiny klasické sociologie. Praha: Slon.

Marada, R. 2003: „Občanský sektor a organizační identita“ In: C. Szaló, I. Nosál (eds.) Mozaika v re-konstrukci. Formování sociálních identit v současné střední Evropě. Brno: IIPS.

Putnam, R. D. et al. 1993. Making Democratic Work: Civic Traditions in Modern Italy. Princeton, NJ: Princeton University Press.

Seippell, O. 2002. „Volunteers and Professionals in Norwegian Sport Organizations.“ Voluntas 13/3: 253-270.

Siegrist, H. 1990. „Professionalization as a Process: Patterns, Progression and Discontinuity“ R. T. Burrage (ed.) Professions in Theory and History. Rethinking the Study of theProfessions. New York: Sage Publications.

Tocqueville, A. de 1992. Demokracie v Americe. Praha: Academia.

Verba, A. 1995. Voice and Equality: Civic Voluntarism in American Politics. Cambridge: Harvard University Press.

Vollmer, H. M., Mills, D. L. (eds.) 1966. Professionalization. New Jersey: Prentice-Hall, Inc. Warren, M. E. 2001. Democracy and Association. Princeton, NJ: Princeton University Press. Weber, M. 1997. Autorita, etika a společnost. Praha: Mladá fronta. 


\section{Autorka}

Magdaléna Št’ovíčková Jantulová působí jako odborná asistentka na Fakultě humanitních studií na Univerzity Karlovy v Praze. V rámci doktorandského programu na oboru sociologie na Fakultě sociálních studií Masarykovy univerzity v Brně v současnosti dokončuje disertační práci věnovanou dilematům procesu profesionalizace českého neziskového sektoru. Kontakt: jantulov@fss.muni.cz 